\title{
PCR and qPCR for detection of Porcine Circovirus type 2 (PCV2) in captive collared (Pecari tajacu) and white-lipped (Tayassu pecari) peccaries from Southern Brazil
}

\section{PCR e qPCR para detecção de Circovírus Suíno tipo 2 (PCV2) em catetos (Pecari tajacu) e queixadas (Tayassu pecari) de cativeiro do Sul do Brasil}

\author{
Leila Sabrina Ullmann ${ }^{1}$; Mara Lucia Gravinatti²; Ricardo Seiti Yamatogi ${ }^{1}$; \\ Leonilda Correia dos Santos ${ }^{3}$; Taís Fukuta da Cruz'; Wanderlei de Moraes ${ }^{3}$; \\ Zalmir Silvino Cubas'; Ivan Roque de Barros Filho ${ }^{5}$; Odilon Vidotto \\ João Pessoa Araújo Junior ${ }^{7}$; Rafael Felipe da Costa Vieira ${ }^{5}$; \\ Alexander Welker Biondo ${ }^{5 *}$
}

\begin{abstract}
Porcine circovirus type 2 (PCV2) is an emergent virus found in commercial pig farms and may cause clinical or subclinical infection. The collared peccary (Pecari tajacu) and white-lipped peccary (Tayassu pecari) may also be infected by PCV2. Accordingly, the aim of this study was to identify PCV2 in whole blood samples of captive peccaries (16 collared and 6 white-lipped) by conventional and quantitative PCR (qPCR). Although the housekeeping gene (c-myc) DNA was successfully amplified, all 22 peccaries tested were negative for PCV2 by both molecular methods. In conclusion, although PCV2 may be endemic in free ranging wild pigs of Central and Northern Brazil, lack of serological and molecular PCV2 evidence (in whole blood) of both captive and free-range wild pigs may indicate low risk of disease in Southern Brazil.
\end{abstract}

Key words: Wildlife swine. Peccary. PCV2.

\footnotetext{
${ }^{1}$ Profs. Drs., Medicina Veterinária Preventiva, Departamento de Microbiologia e Imunologia, Instituto de Biociências, Universidade Estadual Paulista, UNESP, Botucatu, SP, Brasil. E-mail: leila_ullmann@yahoo.com.br; rsyvet@yahoo.com.br; tfcruz@yahoo. com.br

2 Discente do Curso de Mestrado, Programa de Ciências Veterinárias, Universidade Federal do Paraná, UFPR, Curitiba, PR, Brasil. E:mail: maralgravinatti@gmail.com

3 Discentes, Curso de Doutorado, Programa de Ciências Veterinárias, UFPR, Curitiba, PR, Brasil. E-mail: leonildacorreia@gmail. com; wander@itaipu.gov.br

${ }^{4}$ Médicos Veterinários, Santuário Biológico Bela Vista, Itaipu Binacional, Foz do Iguaçu, PR, Brasil. E:mail: zalmir@itaipu.gov. br,wander@itaipu.gov.br

5 Profs. Drs., Departamento de Medicina Veterinária, UFPR, Curitiba, PR, Brasil. E-mail: ivanbarf@ufpr.br; vieirafc@gmail.com; abiondo@ufpr.br

${ }^{6}$ Prof. Dr., Departamento de Medicina Veterinária, Universidade Estadual de Londrina, UEL, Londrina, PR, Brasil. E-mail: vidottro@uel.br

7 Prof. Dr., Departamento de Microbiologia e Imunologia, Instituto de Biociências, UNESP, Botucatu, SP, Brasil. E-mail: jpessoa@ ibb.unesp.br

* Author for correspondence
} 


\section{Resumo}

O circovírus suíno tipo 2 (PCV2) é um vírus emergente encontrado em granjas comerciais de suínos que pode causar infecção clínica ou subclínica. Os catetos (Pecari tajacu) e as queixadas (Tayassu pecari) também podem se infectar com PCV2. Deste modo, o objetivo deste estudo foi identificar o PCV2 em amostras de sangue total de pecaris de cativeiro (16 catetos e seis queixadas) por PCR convencional e quantitativo (qPCR). Embora o gene constitutivo (c-myc) tenha sido amplificado com sucesso, todas as 22 amostras de pecaris avaliadas foram negativas para PCV2 em ambos os métodos moleculares. Em conclusão, embora o PCV2 seja endêmico em suínos selvagens de vida livre do Centro e Norte do Brasil, a ausência de evidência sorológica e molecular de PCV2 (em sangue total) de ambos pecaris de cativeiro e de vida livre no Sul do Brasil podem indicar baixo risco de doença no Sul do Brasil.

Palavras-chave: Pecaris. Pecari. PCV2.

Collared peccary (Pecari tajacu) and whitelipped peccary (Tayassu pecari) are largely distributed in South America (REDFORD; EISENBERG, 1992) belonging to the same order as commercial pigs, but in distinct families (CASTRO et al., 2014). Monitoring peccary health status, mainly for infectious diseases, may be crucial since the Brazilian Institute of Environment and Renewable Natural Resources (IBAMA, 2008) has been regulating commercial farms for meat production and conservation.

Porcine circovirus (PCV) is a small singlestranded DNA, non-enveloped and circular virus found in pigs (ALLAN; ELLIS, 2000), and considered very resistant to inactivation (MARTIN et al., 2008). Two types of virus, a nonpathogenic (type 1- PCV1) and a pathogenic (type 2 - PCV2) have been described (GERBER et al., 2012; CASTRO et al., 2014). PCV2 is a systemic virus with different cellular tropism and may infect respiratory, urinary, reproductive, and digestive systems (ALLAN; ELLIS, 2000; SANCHEZ et al., 2004). Previous studies with commercial pigs have evidenced that PCV2 single infection may not cause clinical manifestations and thus, high prevalence rates may be usually due to subclinical infections (PATTERSON et al., 2015). However, the high mortality rate and consequently economic impact on swine industry may highlight the importance of such potential emergent disease (SLIZ et al., 2015).

Previous studies have shown several domestic swine infectious agents in peccaries (CASTRO et al., 2014), demonstrating that peccaries may play a role as reservoirs for domestic pig diseases. Accordingly, the aim of this study was to identify the PCV2 in whole blood samples by conventional and quantitative PCR (qPCR) of previously surveyed approved under IBAMA and ethical committee for other pathogens (VIEIRA et al., 2011) of adults captive peccaries from Curitiba Zoo in Paraná State, Brazil (16 collared and 6 white-lipped).

EDTA-blood samples previously surveyed for hemotropic mycoplasmas (VIEIRA et al., 2011) were used in this study. DNA was extracted using an available commercial kit (Ilustra $^{\mathrm{TM}}$ GFX $^{\mathrm{TM}}$ Genomic Blood DNA Purification Kit, GE Healthcare, Buckinghamshire, UK), according to the manufacturers' instructions. Real Time PCR reaction was performed with a commercial qPCR Master Mix (GoTaq, Promega, Madison, WI, USA) with standard cycling parameters and melting curve for a commercial PCR system (7300 Real Time, Applied Biosystems, Waltham, MA, USA) using primers 5'-GATGATCTACTGAGACTGTGTGA-3'(sense) and 5'-AGAGCTTCTACAGCTGGGACA-3'(antisense) to detect PCV (PCV1 and PCV2) as previously described (LADEKJAER-MIKKELSEN et al., 2002). A conventional PCR reaction was performed for peccary samples with an odd melting curve 
applying primers for PCV1 and PCV2 as previously described (LAROCHELLE et al., 2000). Cycling conditions were performed as following: $5 \mathrm{~min}$ at $94^{\circ} \mathrm{C}$; 40 cycles with 1 cycle consisting of $1 \mathrm{~min}$ at $94^{\circ} \mathrm{C}, 1 \mathrm{~min}$ at $60^{\circ} \mathrm{C}$, and $1 \mathrm{~min}$ at $72^{\circ} \mathrm{C}$; final extension step of $5 \mathrm{~min}$ at $72^{\circ} \mathrm{C}$.

All 22 peccary samples evaluated were negative for PCV2 by both molecular assays with housekeeping gene DNA (c-myc) successfully amplified and negative and positive controls were also included. A standard curve constructed with plasmid (pGEM Promega) was also included with four dilutions points from $2.96 \times 10^{5}$ to $2.96 \times 10^{2}$. Although peccaries may be potential reservoirs of infectious diseases, captive animals from the present study were also previously negative for Mycoplasma suis by PCR (VIEIRA et al., 2011).

Despite the emergent importance of PCV2 in domestic pigs, PCV2 has been only recently detected in wild pigs from Northern and Central Brazil (CASTRO et al., 2014). The present study may have failed in detect PCV2 in EDTA-blood samples while previous study has used lung and spleen tissues, emphasizing that samples with the highest chance of containing PCV2 DNA may relay on the viral tropism and time of infection. However, another study in Southern Brazil has found no antiPCV2 antibodies in 49 free-ranging white-collared peccaries (GERBER et al., 2012). Since PCV2 is a systemic virus, bloodstream detection would be limited to early acute infection (REAL et al., 2010; GERBER et al., 2012). Further studies should be performed to fully establish whether tissue samples may have higher sensitivity than whole blood for molecular detection of PCV2, and how long antibody levels against PCV2 may be detected in serum of peccaries following infection.

Researches in commercial pigs with intranasally inoculated of PCV and later euthanized, showed 6/8 (75.0\%) different tissues samples testing positive by qPCR, even with no onset clinical signs (NÚÑEZHERNÁNDEZ et al, 2015). And the whole blood of 14 free ranging feral pigs from wildlife areas of Central Brazil have shown that genetic diversity of PCV2 may impair fully establishment of virus infection and maintenance (FRANZO et al., 2015).

Although different wild pig samples from different Brazilian regions have been evaluated in previous studies (REAL et al., 2010; GERBER et al., 2012; CASTRO et al., 2014). The present study has investigated a captive population from Parana State, Southern Brazil while free-ranging peccaries have been evaluated in Central and Northern Brazil, suggesting viral tropism for lymphoid tissues and high viral titers (NAUWYNCK et al., 2012).

In conclusion, although PCV2 may be endemic in free-ranging wild pigs of Central and Northern Brazil, lack of serological and molecular PCV2 evidence in both captive and free-range wild pigs may indicate low risk of disease in Southern Brazil. Moreover, since porcine circovirus has been considered an emergent infectious agent of modern commercial farm systems, further studies should report the epidemiology and wildlife role in viral transmission and wildlife cycle.

\section{References}

ALLAN, G. M.; ELLIS, J. A. Porcine circoviruses: a review. Journal of Veterinary Diagnostic Investigation, Columbia, v. 12, n. 1, p. 3-14, 2000.

CASTRO, A. M. M. G. de; BROMBILA, T.; BERSANO, J. G.; SOARES, H. S.; SILVA, S. O. S.; MINERVINO, A. H. H.; OGATA, R. A.; GENNARI, S. M.; RICHTZENHAIN, L. J. Swine infectious agents in Tayassupecari and Pecaritajacu tissue samples from Brazil. Journal of Wildlife Diseases, Ames, v. 50, n. 2, p. 205-209, 2014.

FRANZO, G.; CORTEY, M.; CASTRO, A. M. M. G. de; PIOVEZAN, U.; SZABO, M. P. J.; DRIGO, M.; SEGALÉS, J.; RICHTZENHAIN, L. J. Genetic characterization of Porcine circovirus type 2 (PCV2) strains from feral pigs in the Brazilian Pantanal: an opportunity to reconstruct the history of PCV2 evolution. Veterinary Microbiology, Amsterdam, v. 178, n. 1-2, p. 158-162, 2015. 
GERBER, P. F.; GALINARI, G. C. F.; CORTEZ, A.; PAULA, C. D.; LOBATO, Z. I. P.; HEINEMANN, M. B. Orbivirus infections in collared peccaries (Tayassutajacu) in Southeastern Brazil. Journal of Wildlife Diseases, Ames, v. 48, n. 1, p. 230-232, 2012.

INSTITUTO BRASILEIRO DO MEIO AMBIENTE E DOS RECURSOS NATURAIS RENOVÁVEIS IBAMA. Instrução Normativa 169, de 20 de fevereiro de 2008. Diário Oficial [da] União, 2008. Disponível em: $\quad<$ http://www.mma.gov.br/port/conama/legiabre. cfm?codlegi=585>. Acesso em: 27 abr. 2016.

LADEKJAER-MIKKELSEN, A. S.; NIELSEN, J.; STADEJEK, T.; STORGAARD, T.; KRAKOWKA, S.; ELLIS, J.; MCNEILLY, F.; ALLAN, G.; BOTNER, A. Reproduction of postweaningmultisystemic wasting syndrome (PMWS) in immunostimulated and nonimmunostimulated 3-week-old piglets experimentally infected with porcine circovirus type 2 (PCV2). Veterinary Microbiology, Amsterdam, v. 89, n. 2-3, p. 97-114, 2002.

LAROCHELLE, R.; BIELANSKI, A.; MÜLLER, P.; MAGAR, R. PCR Detection and evidence of shedding of porcine circovirus type 2 in boar semen. Journal Clinical Microbiology, Washington, v. 38, n. 12, p. 46294632, 2000.

MARTIN, H.; LE POTIER, M. F.; MARIS, P. Virucidal efficacy of nine commercial disinfectants against porcine circovirus type 2. The Veterinary Journal, London, v. 177, n. 3, p. 388-393, 2008.

NAUWYNCK, H. J.; SANCHEZ, R.; MEERTS, P.; LEFEBVRE, D. J.; SAHA, D.; HUANG, L.; MISINZO, G. Cell tropism and entry of porcine circovirus 2 . Virus Research, Amsterdam, v. 164, n. 1-2, p. 43- 45, 2012.

NÚÑEZ-HERNÁNDEZ, F.; PÉREZ, L. J.; MUÑOZ, M.; VERA, G.; TOMÁS, A.; EGEA, R.; CÓRDOBA, S.; SEGALÉS, J.; SÁNCHEZ, A.; NÚÑEZ, J. I. Identification of microRNAs in PCV2 subclinically infected pigs by high throughput sequencing. Veterinary Research, Amsterdam, v. 46, n. 18, p. 1-7, 2015.
PATTERSON, R.; NEVEL, A.; DIAZ, A. V.; MARTINEAU, H. M.; DEMMERS, T.; BROWNE, C.; MAVROMMATIS, B.; WERLING, D. Exposure to environmental stressors result in increased viral load and further reduction of production parameters in pigs experimentally infected with PCV2b. Veterinary Microbiology, Amsterdam, v. 177, n. 3-4, p. 261-269, 2015.

REAL, V. V.; DUTRA, V.; NAKAZATO, L.; FREITAS, T. P. T.; KEUROGHLIAN, A.; ALMEIDA, A. B. P. F.; SOUZA, R. L. PCR of Salmonella spp, Streptococcus suis, Brucella abortus e Porcine circovirus type 2 in freeliving and captive peccaries. Revista Brasileira de Saúde e Produção Animal, Salvador, v. 11, n. 3, p. 858-864, 2010.

REDFORD, K. H.; EISENBERG, J. F. Order Artiodactyla. In: REDFORD, K. H.; EISENBERG, J. F. Mammals of the neotropics: the southern cone. Chicago: University of Chicago, 1992. v. 2, p. 232-235.

SANCHEZ, R.; MEERTS, P.; NAUWYNCK, H. J.; PENSAERT, M. B. Characteristics of porcine circovirus 2 replication in lymphoid organs of pigs inoculated in late-gestation or post natally and possible relation to clinical and pathological outcome of infection. Journal of Veterinary Diagnostic Investigation, Iowa, v. 16, n. 3 , p. 168-178, 2004.

SLIZ, I.; VLASAKOVA, M.; JACKOVA, A.; VILCEK, S. Characterization of porcine parvovirus type 3 and porcine circovirus type 2 in wild boars (Sus scrofa) in Slovakia. Journal of Wildlife Diseases, Ames, v. 51, n. 3, p. 703-711, 2015.

VIEIRA, R. F. C.; MOLENTO, M. B.; GUIMARÃES, A. M. S.; SANTOS, A. P.; BONAT, M.; JAVOROUSKI, M. L.; POPP, L.; SANTOS, L. C.; MORAES, W.; CUBAS, Z. S.; VIEIRA, T. S. W. J.; VIDOTTO, O.; BARROS FILHO, I. R.; BIONDO, A. W.; MESSICK, J. B. Use of a Mycoplasma suis-PCR protocol for screening a population of captive peccaries (Tayassutajacu and Tayassupecari). Revista Brasileira de Parasitologia Veterinária, Jaboticabal, v. 20, n. 1, p. 75-77, 2011. 